\title{
The Implementation of Needle Syringe Exchange Program in Malaysia: A Short Communication
}

\section{Azahah Abu Hassan Shaari}

To Link this Article: http://dx.doi.org/10.6007/IJARBSS/v12-i1/11987

DOI:10.6007/IJARBSS/v12-i1/11987

Received: 12 November 2021, Revised: 19 December 2021, Accepted: 08 January 2022

Published Online: 29 January 2022

In-Text Citation: (Shaari, 2022)

To Cite this Article: Shaari, A. A. H. (2022). The Implementation of Needle Syringe Exchange Program in Malaysia: A Short Communication. International Journal of Academic Research in Business and Social Sciences, 12(1), 1959-1967.

\section{Copyright: $\odot 2022$ The Author(s)}

Published by Human Resource Management Academic Research Society (www.hrmars.com)

This article is published under the Creative Commons Attribution (CC BY 4.0) license. Anyone may reproduce, distribute, translate and create derivative works of this article (for both commercial and non0-commercial purposes), subject to full attribution to the original publication and authors. The full terms of this license may be seen at: http://creativecommons.org/licences/by/4.0/legalcode

Vol. 12, No. 1, 2022, Pg. 1959- 1967

Full Terms \& Conditions of access and use can be found at http://hrmars.com/index.php/pages/detail/publication-ethics 


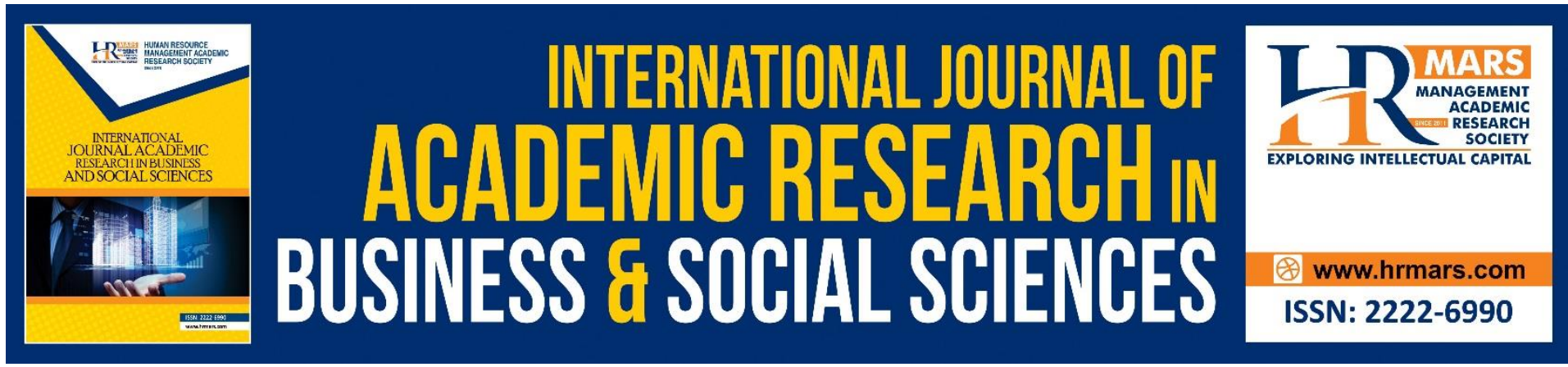

\title{
The Implementation of Needle Syringe Exchange Program in Malaysia: A Short Communication
}

\author{
Azahah Abu Hassan Shaari \\ Faculty of Language Studies and Human Development, Universiti Malaysia Kelantan, 16300 \\ Bachok, Kelantan, Malaysia \\ Email: azahah.ah@umk.edu.my
}

\begin{abstract}
In 2005, the Ministry of Health in Malaysia decided to introduce the needle syringe exchange program to curb the rapid increase of HIV transmission, specifically among people who inject drugs. This short communication paper examines the implementation of the needle syringe exchange program in Malaysia, including an overview of a welfare state that has shaped and influenced access to health care systems in Malaysia. Issues related to legal and socio-cultural context in response to the implementation of the needle exchange program will be discussed. A decrease in HIV cases among Malaysian people will support the social and economic development of the community as a whole. Ultimately, this will support the Malaysian government's commitment to achieving UNAIDS 2030 targets to end AIDS.
\end{abstract}

Keywords: AIDS, HIV, Malaysia, Needle Syringe Exchange, People Who Inject Drugs

\section{HIV in Malaysia}

Historically, sharing contaminated needles, syringes, or other drug-injection equipment has been the main contributor to HIV (human immunodeficiency virus) transmission specifically in Asia (Apenteng et al., 2020; Degenhardt et al., 2017; Golrokhi et al., 2018; Khairudin, 2021; Khan et al., 2018; Zelenev et al., 2016). As a result, countries such as Thailand, Indonesia, China, and Myanmar started their needle syringe exchange program (NSEP) as a method to reduce HIV cases among people who inject drugs (PWID). To date, NSEP plays a crucial role in containing blood-borne viral infections, mainly HIV, Hepatitis $A$, and Hepatitis B (Chandrasekaran et al., 2017; Low et al., 2010; Singh et al., 2016; Yusuff, \& Mohamed, 2018). This program has been practiced in many countries around the world, with Western European countries and Sweden and Australia being among the leaders in the NSEP (Karlsson et al., 2020).

In Malaysia, the total reported HIV/AIDS cases for three decades (1986-2016) were 111,916, and the total reported AIDS-related deaths (1986-2016) estimated reached 18,827 cases (Heng, 2018; Malaysian AIDS Council, 2016). In 2020, the Ministry of Health reported a total of 77,903 people living with HIV. There was a total of 3,564 cases of people newly infected with HIV in 2019, and 986 AIDS-related death were reported in the same year (Ministry of Health, 20210. The primary mode of HIV transmission in Malaysia also continues to be through PWID sharing their needles (Apenteng et al., 2020; Loeliger et al., 2016). Heroin, 
crystalline methamphetamine, and amphetamine-type stimulants (ATS, such as ecstasy, syabu, and yaba) were reported as a drug of choice in Malaysia (Du et al., 2020). In 2005, the Ministry of Health in Malaysia decided to introduce the NSEP in three cities; Johor Bharu, Penang, and Kuala Lumpur to curb the rapid increase of HIV transmission, specifically between PWID.

\section{Aim}

It was estimated that 170,000 people inject drugs in Malaysia (Singh et al., 2016). Consequently, sharing needles and syringes is one of the factors leading to rapid HIV transmission among people who inject drugs (PWID) in Malaysia. A short communication paper discussing the welfare state that shapes the overall health care system in Malaysia, an overview of NSEP implementation within the legal and sociocultural context in Malaysia, and the effectiveness of NSEP in reducing HIV cases will hopefully shed a better understanding of the importance and benefits of the NSEP towards the social development and economical growth of the country.

\section{Objective}

The objectives of this short communication paper are to:

- Understand the implementation of NSEP to reduce HIV cases among people who inject drugs (PWID)

- Explore the welfare state that shapes the overall health care system in Malaysia

- Examine the legal and cultural context in response to the implementation of NSEP to reduce HIV transmission among PWID in Malaysia

\section{Nsep in Malaysia}

It was estimated that 170,000 PWIDs in Malaysia and nearly half reported HIV positive (Singh et al., 2013). In 2005, the Malaysian government agreed to adopt harm reduction measures that consist of two different programs: needle syringe exchange program (NSEP) and Methadone Maintenance Treatment (MMT) as cornerstones to prevent HIV, especially within the PWID (Ministry of Health, 2020). This paper will only examine the NSEP because of its complexity and uniqueness within Malaysia's legal and sociocultural perspectives. Public hospitals oversee the MMT, while the Malaysian AIDS Council (MAC) acts as the main agency that helps the government with NSEP operations.

The MAC is a non-governmental organization (NGO) that was established in 1992 by the Ministry of Health and is the main organization that hires staff, prepares NSEP kits (containing 4 needles and syringes, antiseptic swabs, cotton balls, and condoms), and conducts stakeholder meetings to encourage a better understanding of the NSEP's objectives. As an umbrella for the other non-governmental organizations in Malaysia, the MAC distributed the funds for NGOs to conduct programs related to HIV services and prevention, including the NSEP for PWIDs. Through these NGOs, the NSEP is offered through a drop-incenter (DIC) that has other services including food, hygiene, counseling, and referrals. Since PWID is a hard-to-reach population, the outreach workers who carry the NSEP kit distribute the kits to the 'port' or regular site where PWID meets. The 'port' is an area identified through mapping, a process done before the NSEP to strategically select areas with high numbers of PWID and to identify potential clients. In addition to providing sterile injecting equipment, NSEP also encourages the safe disposal of needles and syringes, dissemination of education prevention related to HIV/AIDS transmission, and promotes the practice of safe sex by 
providing condoms, as well as provide referral services to NSEP clients to other services such as MMT, voluntary counseling and testing, drug treatment and health care services.

The Welfare State in Malaysia

Since matters involving HIV and AIDS are now treated as health care issues, it is critically important to understand how the government in Malaysia shapes the health care system. Economic growth was a priority for the Malaysian government after the Asian financial crisis from 1998 to 1999. Malaysian government's expenditure prioritizes economic development and this sector has received the largest proportion of total government expenditure from 1985 to 2019 compared to the other sectors (Croke et al., 2019). This serves as a government strategy to eradicate poverty-a main government objective since achieving Independence in 1957. In addition, the social services sector that includes education and health care services receives the second-highest budget allocation. This is because the government agrees that the role of education and health care can help eradicate poverty by promoting economic growth, social mobility, and the well-being of the Malaysian population (Hussin et al., 2018).

Malaysia has its economic development, social structures, and political situations that are heavily influenced by the history of British post-colonization, cultural and religious aspects, and the effects of the Asian financial crisis from 1998 to 1999. These factors affect government administration, including the annual expenditure on social policy and social welfare development. Malaysia's government played a dominant and integrated role in health care financing and provision and provide universal health care to its citizens since the well-being of its citizens affects the country's productivity (Hussin et al., 2018; Safurah et al., 2018). Health care is one basic right of citizenship and access to health care services is universal (Bakar et al., 2019). Civil servants enjoy extra privileges in accessing health care services (Hussin et al., 2018). For civil servants, almost all health care services, including the cost of major surgery (including heart surgery, hemodialysis, and cost of maternity care) are offered either free-of-charge or with lower fees compared with health care provided to citizens who work in other sectors, including those in private industry or who are selfemployed. Hospitalizations and medical surgeries are offered with minimal charges, and medicine is offered free in all public hospitals (Lim et al., 2020)

Public Health Care Systems in Malaysia

Government is accountable for ensuring that health care is made accessible to all citizens. Health care services are offered to all Malaysians, despite their social status or economic contributions. The Public Sector Health Expenditure (GCE) of overall healthcare expenses increase from MYR 4.360 million in 1997 to MYR 29 million in 2017, an increase from 4.84 to $7.34 \%$ in 21 years' time (Ministry of Health, 2020). Urbanization increases in national income, and steady population growth, however, have contributed to major changes for the government to continuously provide universal access to health care for their citizens (Ahmad, 2019). The government decided to support the existence of private health care offering various medical services. Private health care will incur charges for their services, making these services available only to those who can afford to pay all the charges. Those who can't afford to pay will need to access the public health care system. Malaysia is a middleincome country where most of its citizens opt for public health care. Overcrowded public hospitals and the long wait times to receive treatment services are still the major problems facing the public health care system (Bakar, 2019; Hussin et al., 2018; Lim et al., 2020). The annual increase in the costs of medication is the other factor that can affect Malaysia's 
capability to provide universal access to health care (Arsih \& Ngah, 2015; Lim et al., 2020; Wong et al., 2019). The government allocates huge amounts of money to buy drugs from pharmaceutical companies but, in return, needs to disperse the medicine free-of-charge to the populace. In 2016, the government expenditures on medicines for public hospitals reached MYR 2.1 billion, which accounted for approximately $37 \%$ of the overall public health sector expenditure (Hamzah et al., 2020).

In Malaysia, Highly Active Antiretroviral Therapy (HAART), a regimen that combines three or more different drugs that have proven to reduce or lower the amount of active HIV was offered as low as MYR 20, compared to MYR 2,000 before the government subsidies (Zahid, 2019). HAART is available to citizens to enhance their quality of life and access to lowcost medication is a major benefit for socio-economically disadvantaged people living with HIV/AIDS. However, the annual increase in medical costs also affects the government's ability to continuously provide HAART at a low-cost (Chong et al., 2021).

\section{Nsep Implementation in Malaysia and its Challenges}

The main goal of NSEP, to disseminate clean and sterile injecting equipment to PWID in Malaysia conflicted with current existing law. In Malaysia, addiction to alcohol and drugs is considered as number one public enemy, and people that are involved with illicit drugs are perceived as imposing social and security threats to the country (Chan, 2016). In 2000, the Malaysian government decided to declare a "Year of Total Wad against Drugs', a strategy that will be used to achieve a drug-free society by 2015. This has to lead to aggressive approaches among the enforcement to arrest individuals that are involved with drugs. For example, Ops Tapis Laws will be applied when law enforcements (Royal Malaysia Police, National AntiNarcotic Agency under the Ministry of Internal Affairs, and Royal Malaysian Customs Department) unite to arrest drug users without a warrant over a specified time at the government rehabilitation centers for a minimum of 2 years. In 2000,80,893 were detained under this law (Reid et al., 2007). Another recent news report in 2017 indicated that 33,500 of 59,000 or $56 \%$ of the total inmates in prisons due to drug offenses (Bernama, 2017). Further, under Section 37 of the Dangerous Act 1952, possession of needles can result in up to 2 years imprisonment. As a result, when NSEP was first introduced, the vast majority of the PWID that are aware of the dangers of being identified by law enforcement are reluctant to participate in NSEP (Sarnon et al., 2011).

In addition to conflicting with current existing laws, the implementation of NSEP also was perceived as inconsistent with the socio-cultural factors, specifical religion in Malaysia. According to Abdullah et al. (2019) and Barmania and Aljunid (2016), Muslim Malays compromise the highest percentages of the total number of the PWID (77.4\%) and people living with HIV (75\%). In 2004, when the Ministry of Health firstly announced their plan to allocate MYR 1 million to implement NSEP to 170,000 PWID, many community leaders protested this program, which eventually delayed NSEP implementation (Hamid et al., 2016; Barmania \& Aljunid, 2016; Vicknasingam \& Mazlan, 2008; Zakaria et al., 2016). They believed that no investments should be made towards a 'self-destructive' and 'wasteful' program, as refer it to the NSEP goal. NSEP was also seen as a potential threat of increasing illicit drug use within society by sending a wrong message to youth, that injecting the drug is normal behavior. 


\section{Nsep to Reduce HIV Transmission in Malaysia}

Despite the conflict with the legal and socio-cultural framework, the efficacy of NSEP to reduce or prevent the HIV epidemic in Malaysia has been documented in a variety of settings (Chandrasekaran et al., 2017; Low et al., 2010; Singh et al., 2013). The 2010 Malaysia Ministry of Health report indicated the success of NSEP in Malaysia in decreasing the average number of new HIV cases per day, from 17 cases in 2005 to 10 cases in 2009. The percentage of new HIV cases in 2008 decreased to 57 percent compared to 70 percent in 2005, before the implementation of NSEP (Malaysian AIDS Council, 2016). By 2014, 78\% of the NSEP services were provided by NOGs and the remaining $22 \%$ were provided by government hospitals (Ministry of Health, 2020). In 2010, NSEP was successful in reaching more than 40,000 PWID, a marginalized and underserved population in Malaysia (Ministry of Health, 2020). In a more recent retrospective cohort study of 20,946 PWID, Chandrasekaran et al. (2017) reported high utilization of NSEP, 85\%, 87\%, and 78\%, of PWID from 2013 to 2015. As a result, in 2015, the Ministry of Health Malaysia reported that the ratio of Malaysian living with HIV has declined from 4 per 100,000 to 0.2 (Ministry of Health Malaysia, 2020). Further, HIV transmission between PWID has been significantly decreased from more than $70 \%$ in 2012 to 11.2 in 2021 (Khairuddin, 2021).

A comparison study of two Behavioral Surveillance Surveys (BSS) that were conducted in April 2006 and February 2007 by the MAC indicated that the provision of free needles and syringes through the NSEP had not increased the number of PWID or the frequency of drug injection between PWID (Sarnon et al., 2011). More recent studies from Wickersham et al. (2016); Singh et al (2016) also found that high utilization of NSEP was related to low HIV transmission between PWID in Malaysia. Hamid et al (2016) also reported $80 \%$ of NSEP clients decided to return the used syringes and needles for an exchange of new and clean injecting equipment.

\section{Conclusion}

This short communication paper examines the implementation of the needle syringe exchange program in Malaysia, including an overview of the welfare state that has shaped and influenced access to health care systems in Malaysia. After 16 years of its implementation, Singh et al. (2016) and Zakaria et al. (2016) reported that police officers in Malaysia are more prepared and ready to accept this program. Further, more community leaders agreed that NSEP's main goal fits with the Islamic principle, dafu al-dharar wa jalbul that views this program as 'an urgent need' to prevent more harm to the society. An ongoing and continuous discussion with stakeholders, including Royal Malaysia Police and community leaders, can enhance a better understanding of the NSEP's main goal. In addition, mobilizing key stakeholders, including health care providers, community networks, NGOs, and law enforcement, is crucial to building a comprehensive environment for HIV prevention with PWID and their partners. Further, implementing targeted behavior change approaches for PWID which emphasize HIV risk reduction, i.e., providing access to psychosocial and medical treatments considered as innovative strategies to address challenges for the delivery of HIV prevention to PWID. A decrease in HIV cases among Malaysian people will support the social and economic development of the community as a whole. Ultimately, this will support the Malaysian government's commitment to achieving UNAIDS 2030 targets to end AIDS.

Through a conceptual analysis of the welfare state and the current legal and social structure in Malaysia, this short communication paper contributes a better understanding of the effectiveness of NSEP to reduce HIV transmission in Malaysia. While NSEP can effectively 
reduce HIV transmission among the PWID, this program is often unwelcome and difficult to set up even in communities hit hardest by the epidemic due to the conflict with the existing drug laws. In the future, there is a need to propose a new model of NSEP that will fit with the political traditions, social structure, and current social conditions in Malaysia.

\section{Statements}

This research received no specific grant from any funding agency in the public, commercial, or not-for-profit sectors.

\section{References}

Abdullah, F., Hashi, A. A., Said, A. H., \& Nor, M. (2019). Medical and Islamic perspectives on Human Immunodeficiency Virus infection and its prevention. IIUM Medical Journal Malaysia, 18(2).

Ahmad, D. (2019). Enhancing sustainability in healthcare delivery: A challenge to the new Malaysia. The Malaysian Journal of Medical Science, 26(1), 1-4. https://doi.org/10.21315/mjms2019.26.1.1

Arsih, B., \& Ngah, A. C. (2015). Challenges in the health care system in Malaysia and Indonesia. Scientific Journal of PPI-UKM, 2(6), 278-281. https://doi.org/10.21315/mjms2019.26.4.9

Apenteng, O. O., Osei, P. P., Oduro, B., Kwabla, M. P., \& Ismail, N. A. (2020). The impact of implementing HIV prevention policies therapy and control strategy among HIV and AIDS incidence cases in Malaysia. Infectious Disease Modelling, 5, 755-765. https://doi.org/10.1016/j.idm.2020.09.009

Bakar, N. S. A., Adilius, M., \& Jabrullah, A. H. (2019). Socioeconomic status affecting inequity of healthcare utilisation in Malaysia, The Malaysian Journal of Medical Sciences,26(4), 79-85.

Barmania, S., \& Aljunid, S. M. (2016). Navigating HIV prevention policy and Islam in Malaysia: Contention, compatibility or reconciliation? Findings from in-depth interviews among key stakeholders. BMC Public Health, 16, Article number 524 https://doi.org/10.1186/s12889-016-3247-y

Bernama. (2017). Some 33,500 convicts in prison because of drug abuse. (2017, June 14). http://english.astroawani.com/malaysia-news/some-33-500-convicts-prison-becausedrug-abuse-146240

Chan, Y. F., Sidhu, G. K., Lim, P. C., \& Wee, E. H. (2016). Students' perceptions of substance abuse among secondary school students in Malaysia. Pertanika Journal of Social Sciences \& Humanities, 24(2), 555-572.

Chandrasekaran, S., Kyaw, N. T. T., Harries, A. D., Yee, I. A., Ellan, P., Kurusamy, T., Yusoff, N., Mburu, G., Mohammad, W. M. Z. W., \& Suleiman, A. (2017.) Enrolment and retention of people who inject drugs in the Needle \& Syringe Exchange Programme in Malaysia. Public Health Action, 7(2), 55-160.

Chong, S. C., Kamarulzaman, A., Azwa, I., Ng, R. X., Chong, M. L., Raman, N., \& Bourne, A. (2021). Delayed HIV testing and treatment seeking, and associated support needs among people living with HIV in Malaysia: A qualitative study. Sexual Health, 18(2), 147155. http://dx.doi.org/10.1071/SH20180

Croke, K., Yusoff, M. B., Abdullah, Z., Hanafiah, M. A. N., Mokhtaruddin, K., Ramli, E. S., Borhan, N. F., Almodovar-Diaz, Y., Atun, R., \& Virk, A. K. (2019). The political economy 
of health financing reform in Malaysia. Health Policy and Planning, 34(10), 732-739. https://doi.org/10.1093/heapol/czz089

Degenhardt, L., Peacock, A., Colledge, S., Leung, J., Grebely, J., Vickerman, P., Stone, J., Cunningham, E. B., Trickey, A., Dumchev, K., \& Lynskey, M. (2017). Global prevalence of injecting drug use and sociodemographic characteristics and prevalence of HIV, HBV, and HCV in people who inject drugs: A multistage systematic review. The Lancet Global Health, 5(12), 1192-1207.

Du, P., Liu, X., Zhong, G., Zhou, Z., Thomes, M. W., Lee, C. W., Bong, C. W., Zhang, X., Hao, F., $\mathrm{Li}, \mathrm{X} .$, \& Zhang, G. (2020). Monitoring consumption of common illicit drugs in Kuala Lumpur, Malaysia, by wastewater-cased epidemiology. International Journal of Environmental Research and Public Health, 17(3), 889-900.

Golrokhi, R., Farhoudi, B., Taj, L., Pahlaviani, F. G., Mazaheri-Tehrani, E., Cossarizza, A., Alinaghi, S., Mohraz, M., \& Voltarelli, F. A. (2018). HIV prevalence and correlations in prisons in different regions of the world: A review article. The Open AIDS Journal, 12, 81-92.

Hamid, S. F. A., Omar, N., Sulaiman, S., Hui, W. S., \& Ismail, R. (2016). Cost Effectiveness of Harm Reduction: Comparison Needle and Syringe Exchange Programme. Journal of Economics, Business and Management, 3(2), 207-211.

Hamzah, N. M., Perera, P. N., \& Rannan-Eliya, R. P. (2020). How well does Malaysia achieve value for money in public sector purchasing of medicines? Evidence from medicines procurement prices from 2010 to 2014. BMC Health Services Research, 20, 1-13.

Heng, E. S. (2018). Get Rid of HIV/AIDS Stigma, Sarawak Daily News, Malaysia. http://www.theborneopost.com/2017/05/14/get-rid-of-hivaids-stigma/.

Hussin, M. F. A., Salleh, M. A., Hehsan, A., \& Junaidi, J. (2018). The roles of non-state actors in eradicating poverty in Malaysia, Conference Series: Earth and Environmental Science, 175(1).

Karlsson, N., Berglund, T., Ekström, A. M., Hammarberg, A., \& Tammi, T. (2020). Could 30 years of political controversy on needle exchange programmes in Sweden contribute to scaling-up harm reduction services in the world? Nordic Studies on Alcohol and Drugs, 38(1), 66-88

Khairuddin, L. (2021). Cost of Living with HIV in Malaysia. Penang Institute. https://penanginstitute.org/programmes/penang-institute-in-kuala-lumpur/1031cost-of-living-with-hiv-in-malaysia/

Khan, F., Krishnan, A., Ghani, M. A., Wickersham, J.A ., Fu, J. J., Lim, S. H., Dhaliwal, S. K., Kamarulzaman, A., \& Altice, F. L. (2018). Assessment of an innovative voluntary substance abuse treatment program designed to replace compulsory drug detention centers in Malaysia. Substance Use \& Misuse, 53(2), 249-259.

Lim, S. C., Yap, Y. C., Barmania, S., Govender, V., Danhoundo, G., \& Remme, M. (2020). Prioritysetting to integrate sexual and reproductive health into universal health coverage: The case of Malaysia. Sexual and Reproductive Health Matters, 28(2), 842153.

Loeliger, K. B., Marcus, R., Wickersham, J. A., Pillai, V., Kamarulzaman, A., \& Altice, F. L. (2016). The syndemic of HIV, HIV-related risk and multiple co-morbidities among women who use drugs in Malaysia: Important targets for intervention. Addictive Behaviors, 53, 31-39.

Low, W. Y., Yeap, R., \& Tong, W. T. (2010). Achieving the UN's millennium development goal in combating HIV and AIDS: The Malaysia scenario. Asian J. WTO \& Int'l Health L \& Pol'y, 5, 427. 
Malaysian AIDS Council and Malaysian AIDS Foundation. (2016). Snapshot of HIV \& AIDS in Malaysia 2016. https://www.mac.org.my/v3/wpcontent/uploads/2017/11/Snapshot-of-HIV-AIDS-in-Malaysia

2016_Brochure_31072017-Web.pdf

Ministry of Health. (2020). Global AIDS Monitoring. Malaysia HIV/AIDS Progress Report. https://www.moh.gov.my/moh/resources/Penerbitan/Laporan/Umum/Laporan_Glob al_AIDS_Monitoring_2020_new.pdf

Reid, G., Kamarulzaman, A., \& Sran, S. K. (2007). Malaysia and harm reduction: The challenges and responses. International Journal of Drug Policy, 18 (2), 136-140.

Safurah, J., Nor Asiah, M., Normi, M., MuhamadIrfanYasin, A. U., Subashini, A., Nazrila, H. N., Ruziaton, H., Sarmiza, S., Zaleha, J., Norlizah, P., \& Rokiah, M. (2018). Working towards universal health coverage through the family doctor concept in Malaysia, International Journal of Medical and Health Sciences, 7(3), 98-106.

Singh, D., Chawarski, M. C., Schottenfeld, R., \& Vicknasingam, B. (2013). Substance abuse and the HIV situation in Malaysia. Journal of Food and Drug Analysis, 21(4), S46-S51.

Singh, P. S. J., Azman, A., Samsurijan, M. S., Badaruddin, R. F. R., Vadevelu, K., Yahaya, M. H., \& Latiff, A. R. A. (2016). Implementation dilemmas of the needle syringe exchange programme (NSEP): Between the law and prevention. Pacific Science Review B: Humanities and Social Sciences, 2(2), 53-57.

Vicknasingam, B., \& Mazlan, M. (2008). Malaysian drug treatment policy: An evolution from total abstinence to harm reduction. Jurnal Antidadah Malaysia, 3, 107-121.

Wickersham, J. A., Loeliger, K. B., Marcus, R., Pillai, V., Kamarulzaman, A., \& Altice, F.L. (2016). Patterns of substance use and correlates of lifetime and active injection drug use among women in Malaysia. The American Journal of Drug and Alcohol Abuse, 42(1), 98-110.

Wong, S. L., Ibrahim, S., Kadir, N. A., \& Salleh, S. M. (2019). Access and affordability of medicines in Malaysia: Need for a national pricing policy. Applied Health Economics and Health Policy, 17(5), 641-654.

Yusuff, I., Md, Y., \& Mohamed, M. (2018). Scientific imperatives in entailing the legitimacy for harm reduction approach to drug use: Reduction of HIV incidence. Indian Journal of Public Health Research \& Development, 9(11).

Zahid, S. J. (2019). Amid debate over regulating price of medicine in Malaysia, cost of HIV drugs hits record low Monday. Free Malaysia Today.

https://www.malaymail.com/news/malaysia/2019/07/15/amid-debate-over-

regulating- price-of-medicine-in-malaysia-cost-of-hiv-drugs/1771403

Zakaria, E., Sarnon, N., Ibrahim, F., Saleem, M., Hoesni, S. M., \& Manap, J. (2016). Drug law enforcement dilemmas in practicing discretion of the needle and syringe exchange program (NSEP). Science International, 27(6), 6335-6340.

Zelenev, A., Long, E., Bazazi, A. R., Kamarulzaman, A., \& Altice, F. L. (2016). The complex interplay of social networks, geography and HIV risk among Malaysian drug injectors: Results from respondent-driven sampling. International Journal of Drug Policy, 37, 98106. 